\title{
PENGARUH TINGKAT BAGI HASIL DAN TINGKAT SUKU BUNGA TERHADAP SIMPANAN DEPOSITO (STUDI KASUS PADA PT.BANK NAGARI UTAMA PADANG)
}

\author{
Nadya Jumraatul Yesha ${ }^{1}$, Muhammad Rivandi ${ }^{2}$ \\ Sekolah Tinggi Ilmu Ekonomi "KBP" \\ Email: Nadyajumratulyesha@gmail.com \\ Muhamamdrivandi@akbpstie.ac.id
}

\begin{abstract}
Banks are financial institutions that play an important role in the country's economy, one of which is by increasing the collection of funds from the public. The purpose of this study was to determine the effect of profit sharing and interest rates on mudharabah deposits at PT. Bank Nagari Utama Padang. The object of research at PT. Bank Nagari Utama Padang. Data used in the form of time series totaling 30 data. Data analysis method uses multiple linear regression. The results showed that the profit sharing and interest rates had a positive and significant effect on deposits at PT. Bank Nagari Utama Padang.
\end{abstract}

Keywords: Profit Sharing, Interest Rate and Deposits

\begin{abstract}
ABSTRAK
Bank merupakan lembaga keuangan yang berperan penting pada perekonomian Negara, salah satunya dengan meningkatkan penghimpunan dana dari masyarakat. Tujuan penelitian ini adalah untuk mengetahui pengaruh tingkat bagi hasil dan tingkat suku bunga terhadap simpanan deposito mudharabah pada PT. Bank Nagari Utama Padang.Objek penelitian pada PT. Bank Nagari Utama Padang. Data yang digunakan dalam bentuk time series yang berjumlah 30 data.Metode analisis data menggunakan regresi linier berganda.Hasil penelitian menunjukkan bahwa tingkat bagi hasil dan tingkat suku bunga berpengaruh positif dan signifikan terhadap simpanan deposito pada PT.Bank Nagari Utama Padang.
\end{abstract}

Kata Kunci : Tingkat Bagi Hasil, Tingkat Suku Bunga dan Simpanan Deposito

\section{PENDAHULUAN}

Bank merupakan lembaga keuangan yang berperan penting pada perekonomian Negara, salah satunya dengan meningkatkan penghimpunan dana dari masyarakat. Semakin berkembang industry perbankan maka akan semakin baik pula perekonomian Negara kita. Bank berfungsi untuk menghimpun dana dan menyalurkannya kepada masyarakat dalam 
meningkatkan perkembangan perekonomian, salah satunya pada bank syariah yaitu dengan menghimpun dana dan menyalurkannya dengan deposito atau dana pihak ketiga. Deposito ini dijadikan nasabah sebagai alat untuk berinvestasi bagi yang memiliki kelebihan dana. Faktorfaktor yang dapat mempengaruhi deposito itu sendiri ialah tingkat suku bunga dan tingkat bagi hasil. Perubahan sedikit saja yang terjadi pada tingkat deposito dapat mempengaruhi performa pada bank (Lusiani, 2017).

Berdasarkan Undang-undang No.10/1998 tentang perubahan Undang-undang No.7/1992 tentang perbankan dalam Latumaerissa (2013) deposito adalah simpanan yang penarikannya hanya dapat dilakukan pada waktu tertentu berdasarkan perjanjian nasabah penyimpan dengan bank. Jadi yang dimaksud dengan deposito adalah suatu simpanan yang memiliki jangka waktu tertentu misalnya 1 bulan, 3 bulan, 6 bulan, dan seterusnya, simpanan tersebut hanya dapat dicairkan ketika jangka waktunya habis.

Deposito merupakan tempat nasabah untuk melakukan investasi dalam bentuk suratsurat berharga.Pemilik deposito disebut dengan deposan. Kepada setiap deposan akan diberi imbalan bunga atas depositnya. Bagi bank, bunga yang diberikan kepada deposan adalah bunga yang tertinggi, jika dibandingkan dengan simpanan giro atau tabungan, deposito dianggap bank lebih mahal. Deposito memiliki jangka waktu jatuh tempo mulai 1 bulan, 3 bulan, 6 bulan, 12 bulan, 18 bulan sampai 24 bulan (Kasmir, 2013).

Simpanan deposito menurut Kasmir (2012) merupakan simpanan jenis ketiga pada bank yang mengandung unsur jangka waktu lebih panjang, tidak bisa ditarik setiap saat. Apabila nasabah menyimpan dana sesuai waktu yang telah ditentukan misalnya jangka waktunya 3 bulan, maka dana yang diinvestasikan hanya dapat dicairkan setelah jangka waktunya berakhir. Sarana yang digunakan untuk menarik uang pada deposito tergantung dari jenis depositonya, jika deposan menggunakan deposito berjangka maka sarana alat yang digunakan adalah bilyet deposito.

\section{TINJAUAN PUSTAKA \\ Deposito}

Deposito merupakan tempat nasabah untuk melakukan investasi dalam bentuk suratsurat berharga. Pemilik deposito disebut dengan deposan. Kepada setiap deposan akan diberi imbalan bunga atas depositnya. Bagi bank, bunga yang diberikan kepada deposan adalah bunga yang tertinggi, jika dibandingkan dengan simpanan giro atau tabungan, deposito dianggap bank lebih mahal. Deposito memiliki jangka waktu jatuh tempo mulai 1 bulan, 3 bulan, 6 bulan, 12 bulan, 18 bulan sampai 24 bulan (Kasmir, 2013).

Deposito menurut Kasmir(2007) adalah produk simpanan di bank yang penyetorannya maupun penarikannya hanya bisa dilakukan pada waktu tertentu saja. Deposito merupakan salah satu produk keuangan yang berbentuk surat berharga. Deposito biasanya dikeluarkan oleh pihak-pihak yang membutuhkan dana tambahan dari pihak luar yang memiliki dana lebih. Pihak luar yang menyetorkan dana untuk mendapatkan deposito nantinya akan mendapatkan balas jasa berupa tingkat pengembalian dengan jumlah tertentu.

\section{Bagi Hasil}

Bagi hasil adalah sebuah bentuk pengembalian dari kontrak investasi, berdasarkan suatu periode tertentu dengan karakteristiknya yang tidak tetap dan tidak pasti besar kecilnya perolehan tersebut. Karena perolehan itu sendiri bergantung pada hasil usaha yang terjadi. Perbankan syariah pada umumnya mengaplikasiannya dengan menggunakan sistem profit sharing maupun revenue sharing tergantung kepada kebijakan masing-masing bank untuk memilih salah satu dari sistem yang ada (Saleh, 2002).

Sistem bagi hasil adalah suatu sistem yang meliputi tata cara pembagian hasil usaha antara penyediaan dengan pengelola dana. Pembagian hasil usaha ini dapat terjadi antara 
bank dan penyimpan dana, maupun antara bank dengan nasabah penerima dana. Bentuk produk bagi hasil yang berdasarkan prinsip bank syariah ada 2 yaitu mudharabah dan musyarakah (Yaya, 2014).

\section{Suku Bunga}

Bunga adalah imbalan jasa atas pinjaman uang, imbalan jasa ini merupakan suatu kompensasi kepada pemberi pinjaman atas manfaat kedepan dari uang pinjaman tersebut apabila diinvestasikan. Jumlah pinjaman tersebut disebut " pokok utang" (principal). Persentase dalam pokok utang yang dibayarkan sebagai imbal jasa (bunga) dalam suatu periode tertentu disebut "suku bunga" (Utomo, 2016).

Perubahan suku bunga dapat mengakibatkan perubahan keuntungan bank. Hal ini disebabkan karena adanya ketidakcocokan antara suku bunga asset dan suku bunga kewajiban. Kewajiban bank merupakan instrument jangka pendek, lebih sensitif terhadap perubahan suku bunga dibandingkan asset bank yang merupakan instrument jangka panjang. Dan akibatnya kenaikan suku bunga dapat mengakibatkan meningkatnya pembayaran atas kewajiban dibandingkan kenaikan penerimaan asset (Mangani, 2009).

\section{Hipotesis \\ Pengaruh Tingkat Bagi Hasil terhadap Simpanan Deposito}

Berdasarkan penelitian .Reswari \& Abdurahim (2010) dan Alinda \& Riduwan(2016) bagi hasil terhadap simpanan deposito mudharabah menemukan pengaruh positif signifikan terhadap simpanan deposito mudharabah. Tingkat bagi hasil mengalami kenaikan maka simpanan deposito akan mengalami kenaikan, hasil penelitian ini sesuai dengan teori floating market yang menyatakan nasabah yang menyimpan uang dibank mengharapkan tingkat keuntungan deposito yang ditawarkan oleh bank. Penelitian yang ditemukan Natalia, Ar, \& Rahayu (2014) menemukan hubungan yang berbeda, yaitu tingkat bagi hasil berpengaruh negatif terhadap deposito mudharabah, yang artinya apabila tingkat bagi hasil tidak stabil ataupun menurun maka keinginan nasabah untuk menyimpan dananya dalam bentuk deposito akan menurun pula. Karena nasabah cenderung menginvestasikan dananya sesuai dengan tingkat keuntungan yang akan diperoleh.

Hasil ini bertolak belakang oleh peneliti Farizi \& Riduwan(2016) bahwa tingkat bagi hasil tidak mempunyai pengaruh terhadap simpanan deposito mudharabah. Hal ini disebabkan oleh karakter nasabah emosional yang non profit oriented. Bahwa faktor untuk mendapatkan return yang tinggi tidak menjadi dasar dalam menentukan bank melainkan sesuai dengan syariah dan bahwa bagi hasil tidak mempunyai pengaruh pada pertumbuhan dana di bank umum syariah. Berdasarkan Teori dan hasil penelitian maka diturunkan hipotesis yang akan dibuktikan secara empiris :

\section{$\mathrm{H}_{1}$ : Tingkat Bagi Hasil berpengaruh positif terhadap Simpanan Deposito}

\section{Pengaruh Tingkat Suku Bunga terhadap Simpanan Deposito}

Penelitian tingkat suku bunga pada simpanan deposito yang dilakukanIskandar \& Firdaus(2004) dan Farizi \& Riduwan (2016) menemukan hasil bahwa tingkat suku bunga berpengaruh signifikan positif pada deposito mudharabah. Hal ini diakibatkan apabila tingkat suku bunga naik jumlah deposito tidak akan mengalami perubahan drastis. Perubahan dari deposito, nasabah akan tetap menginvestasikan dananya sehingga nasabah syariah tidak menarik dananya dan beralih ke konvensional

Berbeda dengan penelitian Natalia, Ar, \& Rahayu (2014)dan Alinda \& Riduwan (2016) menemukan bahwa tingkat suku bunga tidak mempunyai pengaruh terhadap jumlah simpanan deposito mudharabah. Faktor penyebabnya kemungkinan karena situasi ekonomi yang baik, sehingga dapat memberi keuntungan apabila dana disimpan dalam bentuk deposito. Apabila tingkat suku bunga berubah maka tidak akan berpengaruh pada deposito, dikarenakan 
keyakinan nasabah terhadap suku bunga sangat bertentangan dengan agama. Berdasarkan Teori dan hasil penelitian maka diturunkan hipotesis yang akan dibuktikan secara empiris :

\section{$\mathrm{H}_{2}$ : Tingkat Suku Bunga berpengaruh positif terhadap Simpanan Deposito}

\section{METODOLOGI PENELITIAN}

Jenis penelitian ini adalah penelitian korelasional dengan pendekatan kuantitatif. Objek penelitian peneliti pada Bank Nagari Utama Padang. Bank Nagari Utama Padang bergerak dibidang jasa yaitu jasa keuangan. Produk yang dikeluarkan Bank Nagari adalah nagari money (N-Money), tabungan sikoci bisnis, sikoci pendidikan, tabungan sikoci pensiunan, tabungan sikoci rencana, deposit box, deposit dan giro.

Jenis data didalam penelitian ini adalah time series. Pengukuran yang digunakan dalam time series adalah data rasio. Dimana data rasio merupakan merupakan data tentang keterangan yang memberikan nilai yang diukur dari nilai absolut. Sumber data penelitian ini mengambil laporan keuangan pada PT.Bank Nagari Utama Padang.

Teknik pengumpulan data yang dipakai dalam penelitian ini adalah metode dokumentasi pengumpulan data dengan pengamatan, dimana peneliti tidak terlibat langsung dalam aktivitas tapi hanya sebagai pengamat independen. Dokumentasi data didalam penelitian dengan mengumpulkan laporan keuangan bank Nagari Utama Padang dari Juli 2015 sampai Desember 2017. Dimana dari data laporan keuangan bulanan bank Nagari Utama Padang yaitu data yang akan diambil tingkat bagi hasil dan simpanan deposito, tingkat suku bunga diambil dari BI Rate Bank Indonesia.

\section{Definisi Operasional Variabel}

Deposito menurut Kasmir(2007) adalah produk simpanan di bank yang penyetorannya maupun penarikannya hanya bisa dilakukan pada waktu tertentu, pengukuran simpanan deposito adalah nominal atau jumlah simpanan deposito Alinda \& Riduwan(2016).Bagi hasil adalah suatu penyaluran yang ditunjukkan untuk kepentinga investasi dalam perbankan islam yang dapat dilakukan berdasarkan akad bagi hasil Utomo (2016), pengukuran bagi hasil diperoleh dari laporan keuangan Bank Nagari Utama dalam bentuk persen (\%) Alinda \& Riduwan (2016). Bunga bank dapat diartikan sebagai harga yang harus dibayar kepada nasabah (dan harga yang harus dibayar oleh nasabah kepada bank Kasmir (2012), pengukuran suku bunga yaitu tingkat suku bunga bank Indonesia (BI rate) yang menjadi acuan bagi bank yang beroperasi di Indonesia dalam bentuk persen (\%) (Alinda \& Riduwan, 2016).

Analisis data menggunakan metode data regresi linear berganda dengan menggunakan SPSS 23 for windows.pengujian hipotesis yang terdiri uji $t$ dan koefisien determinasi (Uji $\mathrm{R}^{2}$ ). Uji $\mathrm{t}$ merupakan suatu uji statistik yang digunakan untuk melihat sejauh mana pengaruh variabel independen terhadap variabel secara parsial atauDjuniadi et al.(2016)Kriteria Pengujian: a) Jika prob $\leq$ alpha 0,05 maka keputusannya adalah Ho ditolak dan Ha diterima maka dapat disimpulkan bahwa variabel independen berpengaruh signifikan terhadap variabel dependen secara individual. b)Jika prob $>$ alpha 0,05 maka keputusannya adalah Ho diterima dan Ha ditolak maka dapat disimpulkan bahwa variabel independen tidak berpengaruh signifikan terhadap variabel dependen secara individual.

Uji koefisien determinasi (Uji $\mathrm{R}^{2}$ ) untuk mengetahui seberapa jauh variasi variabel independen dapat menerangkan dengan baik variasi variabel dependen. Untuk mengukur kebaikan suatu model (goodness of fit), digunakan koefisien determinasi $\left(\mathrm{R}^{2}\right)$.kriteria yang digunakan meliputi: a) Nilai $\mathrm{R}^{2}$ yang kecil atau mendekati nol, berarti kemampuan variabelvariabel bebas dalam menjelaskan variasi variabel tidak bebas dan sangat terbatas. $b$ ) 
Nilai $\mathrm{R}^{2}$ mendekati satu, berarti kemampuan variabel-variabel bebas dalam menjelaskan hamper semua informasi yang digunakan untuk memprediksivariasi variabel tidak bebas (Djuniadi et al., 2016).

HASIL DAN PEMBAHASAN Statistik Deskriptif

Tabel 1

Hasil Uji Statistik Deskriptif

\begin{tabular}{|l|r|r|r|r|r|}
\hline \multicolumn{7}{|c|}{ Descriptive Statistics } \\
\hline & $\mathrm{N}$ & Minimum & Maximum & Mean & Std. Deviation \\
\hline $\begin{array}{l}\text { Simpanan } \\
\text { Deposito }\end{array}$ & 30 & 5997474.00 & 8797156.00 & 7393538.800 & 675543.2901 \\
\hline $\begin{array}{l}\text { Tingkat Bagi } \\
\text { Hasil }\end{array}$ & 30 & 5.00 & 6.40 & 5.4017 & .32283 \\
\hline $\begin{array}{l}\text { Tingkat Suku } \\
\text { Bunga }\end{array}$ & 30 & 4.25 & 7.50 & 5.7250 & 1.28209 \\
\hline Valid N (listwise) & 30 & & & & \\
\hline
\end{tabular}

\section{Sumber: olah data statistik SPSS 23}

Pada gambaran statistik deskriptif pada tabel 1 bahwa dapat dijelaskan bahwa penelitian ini menggunakan data laporan keuangan bulanan Bank Nagari Utama Padang dengan tahun pengamatan dari bulanJuli 2015 sampai bulan Desember 2017 maka jumlah data pengamatan dari Bank Nagari Utama adalah 30 sampel yang akan dilakukan pengujian.Nilai simpanan deposito terendah yang dimiliki Bank Nagari Utama Padang adalah sebesar Rp5.997.474, sedangkan nilai simpanan depositomudharabah tertinggi yang dimiliki bank Nagari Utama Padang adalah sebesar Rp. 8.797.156. Secara keseluruhan pada umumnya Bank Nagari Utama Padang yang digunakan dalam penelitian ini memiliki ratarata simpanan deposito sebesar Rp. 7.393.538,800yang menghasilkan standar deviasi sebesar Rp. 675.543,2901. Nilai tingkat bagi hasil terendah yang dimiliki Bank Nagari Utama Padangadalah sebesar 5\%, sedangkan nilai tingkat bagi hasil tertinggi yang dimiliki Bank Nagari Utama Padang adalah sebesar 6,40\%. Secara keseluruhan pada umumnya Bank nagari Utama Padang yang digunakan dalam penelitian ini memiliki rata-rata $5,4017 \%$ yang menghasilkan standar deviasi sebesar 0,32283\%.Nilai tingkat suku bunga terendah yang dimiliki Bank Nagari Utama Padang adalah sebesar4,25\% sedangkan nilai tingkat suku bunga tertinggi yang dimiliki Bank Nagari Utama Padang adalah sebesar 7,50\%. Secara keseluruhan pada umumnya Bank Nagari Utama Padang yang digunakan dalam penelitian ini memiliki rata-rata 5,7250\% yang menghasilkan standar deviasi 1,28209\%. 


\section{Regresi Linear Berganda}

Tabel 2

Regresi Linier Berganda

\begin{tabular}{|c|c|c|c|}
\hline \multirow[b]{3}{*}{ Model } & \multicolumn{3}{|c|}{ Coefficients $^{\mathrm{a}}$} \\
\hline & \multicolumn{2}{|c|}{ Unstandardized Coefficients } & $\begin{array}{l}\text { Standardized } \\
\text { Coefficients }\end{array}$ \\
\hline & $\mathrm{B}$ & Std. Error & Beta \\
\hline $\begin{array}{l}1 \text { (Constan } \\
\text { t) }\end{array}$ & 14,451 & 276 & \\
\hline $\mathrm{TBH}$ & ,220 &, 045 & ,762 \\
\hline TSB &, 030 &, 011 & ,415 \\
\hline
\end{tabular}

a. Dependent Variable: simpanan deposito

Sumber: olah data statistik SPSS 23

Pada table 2 dari hasil diatas maka persamaan regresinya adalah:

$$
\mathrm{Y}=14,451+0,220 \mathrm{X}_{1}+0,030 \mathrm{X}_{2}+\mathrm{e}
$$

Berdasarkan tabel 2 menunjukkan model regresi dilihat dari nilai konstanta yang dihasilkan adalah sebesar 14,451 nilai yang akan diperoleh tersebut bahwa menunjukkan jika diasumsikan terjadi perubahan (kenaikan) variabel Tingkat Bagi Hasil dan Tingkat Suku Bunga maka nilai perolehan simpanan deposito adalah sebesar 14,451. Model regresi pada variabel tingkat bagi hasil menunjukkan bahwa nilai koefisien regresi bertanda positif sebesar 0,220 . Nilai koefisien yang diperoleh bahwa menunjukkan ketika diasumsikan terjadi peningkatan nilai tingkat bagi hasil sebesar 1\%, maka akan meningkatkan simpanan deposito pada Bank Nagari Utama Padang sebesar 0,220 dengan asumsi selain faktor lain Tingkat Bagi Hasil dianggap tetap atau konstan (tetap). Model regresi pada variabel tingkat suku bunga menunjukkan jumlah nilai koefisien regresi bertanda positif sebesar 0,030. Nilai koefisien yang diperoleh menunjukkan bahwa ketika diasumsikan terjadi peningkatan nilai tingkat suku bunga sebesar 1\%, maka akan meningkatkan simpanan deposito pada Bank Nagari Utama sebesar 0,030 dengan asumsi selain faktor lain yaitu tingkat suku bunga dianggap tetap atau konstan (tetap).

\section{Uji t}

Tabel 3

Hasil Uji t-Parsial

\section{Coefficients $^{\mathrm{a}}$}

\begin{tabular}{|ll|l|l|}
\hline \multicolumn{2}{|l|}{} & & \\
\multicolumn{2}{|l|}{ Model } & $\mathrm{T}$ & Sig. \\
\hline 1 & (Constant) & 52,291 &, 000 \\
& TBH & 4,915 &, 000 \\
& TSB & 2,675 &, 012 \\
\hline
\end{tabular}

a. Dependent Variable: Simpanan deposito

Sumber: olah data statistik SPSS 23 
Pada tabel 3melakukan pengujian $\mathrm{t}$ dapat digambarkan bahwa tingkat bagi hasil diperoleh nilai sig sebesar 0,000 . Proses pengolahan data dilakukan dengan menggunakan tingkat kesalahan sebesar 0,05 . Hasil yang diperoleh menunjukkan bahwa nilai sig $0,000<0,05$ sehingga dapat disimpulkan bahwa tingkat bagi hasil berpengaruh positif dan signifikan terhadap simpanan depositoBank Nagari Utama Padang.Tingkat suku bunga diperoleh nilai sig sebesar 0,012. Dalam proses pengolahan data dilakukan dengan menggunakan tingkat kesalahan sebesar 0,05 . Hasil yang diperoleh menunjukkan bahwa nilai sig $0,012<0,05$ sehingga dapat disimpulkan bahwa tingkat suku bunga berpengaruh positif dan signifikan terhadap simpanan depositoBank Nagari Utama Padang.

\section{Uji Determinasi $\left(\mathbf{R}^{2}\right)$}

\section{Tabel 4}

\section{Hasil Uji Koefisien Determinasi $\left(\mathbf{R}^{2}\right)$}

\begin{tabular}{|l|c|c|c|c|}
\hline \multicolumn{6}{|c|}{ Model Summary $^{\text {b }}$} \\
\hline Model & $\mathrm{R}$ & R Square & $\begin{array}{c}\text { Adjusted R } \\
\text { Square }\end{array}$ & $\begin{array}{c}\text { Std. Error of the } \\
\text { Estimate }\end{array}$ \\
\hline 1 & $.690^{\mathrm{a}}$ & .476 & \multicolumn{4}{c|}{.437} & .06996 \\
\hline \multicolumn{2}{|l|}{ a. Predictors: (Constant), Tingkat Suku Bunga, Tingkat Bagi Hasil } \\
\hline \multicolumn{2}{|l}{ b. Dependent Variable: Simpanan Deposito } \\
\hline
\end{tabular}

\section{Sumber: olah data statistik SPSS 23}

Pada tabel 4 melakukan pengujian $R$ square diperoleh hasil nilai R-Square adalah 0,476 . Hasil yang diperoleh dapat menunjukkan bahwa tingkat bagi hasil dan tingkat suku bunga memiliki variasi konstribusi dalam mempengaruhi simpanan deposito sebesar $47,6 \%$ sedangkan sisanya $52,4 \%$ dipengaruhi oleh variabel lain yang tidak diteliti dalam penelitian ini seperti inflasi, kurs rupiah, finance to deposit ratio (FDR) dan lainnya.

\section{PEMBAHASAN}

\section{Pengaruh Tingkat Bagi Hasil terhadap Simpanan Deposito}

Berdasarkanuji tmenunjukkan hasil tingkat bagi hasil berpengaruh positif dan signifikan terhadap simpanan depositopada Bank Nagari Utama Padang. Hasil penelitian ini sejalan dengan penelitian yang dilakukanAlinda \& Riduwan (2016) ; Reswari \& Abdurahim(2010)yang menemukan tingkat bagi hasil berpengaruh positif dan signifikan terhadap simpanan depositomudharabah. Berpengaruhnya tingkat bagi hasil terhadap simpanan depositomudharabah, dikarenakan adanya pengaruh hubungan searah antara tingkat bagi hasil dan simpanan depositomudharabah tersebut, yang artinya semakin tinggi tingkat bagi hasil maka akan meningkatkan simpanan depositomudharabah. Hal tersebut sesuai dengan teori floating market bahwa sebagian nasabah yang menyimpan uangnya di bank, penyebabnya lebih ketingkat keuntungan dan kualitas layanan yang ditawarkan oleh bank. Apabila tingkat bagi hasil naik maka nasabah akan menyimpan dananya dalam jumlah besar, agar mendapatkan keuntungan yang tinggi, ini dikarenakan sebagian nasabah mempunyai sifat yang lebih mengutamakan keuntungan (Alinda \& Riduwan, 2016).

Tingkat bagi hasil pada PT.Bank Nagari Utama Padang bulan Juli 2015 sampai bulan Desember 2017 secara keseluruhan berfluktuasi, peningkatan ini dapat mempengaruhi jumlah simpanan deposito mudharabah. Sebagian nasabah Bank Nagari Utama Padang di Sumatera Barat lebih mengutamakan keuntungan yang diberikan oleh pihak bank, salah satunya melalui tingkat bagi hasil yang tinggi. Tingkat bagi hasil yang tinggi nasabah mempercayai dananya dalam bentuk deposito pada Bank Nagari Utama Padang agar memperoleh keuntungan yang lebih tinggi, hal ini sesuai dengan teori floating marketbahwa nasabah di 
bank lebih mengutamakan kualitas yang ditawarkan pihak bank serta keuntungan yang dapat diperoleh.

\section{Pengaruh Tingkat Suku Bunga terhadap Simpanan Deposito}

Berdasarkan uji tmenunjukkan hasil bahwa tingkat suku bunga berpengaruh positif dan signifikan terhadap simpanan deposito.Penelitian ini mendukung penelitian Farizi \& Riduwan (2016) ; Iskandar \& Firdaus(2004) menyatakan bahwa tingkat suku bunga berpengaruh positif dan signifikan terhadap simpanan deposito mudharabah. Tingginya minat nasabah menabung dibank dipengaruhi oleh faktor suku bunga. Makin tinggi tingkat suku bunga maka jumlah simpanan deposito makin meningkat. Konsep ini berbeda dengan perbankan syariah yang menggunakan sistem bagi hasil atas penggunaan dana oleh pihak peminjam.

Tingkat suku bunga pada PT.Bank Nagari Utama Padang berdasarkan data dari laporan keuangan bulanan dari bulan Juli 2015 sampai bulan Desember 2017 dapat diinterpretasikan bahwa tingkat suku bunga berfluktuasi. Berdasarkan faktor utama yang mempengaruhi tingkat suku bunga pada PT.Bank Nagari Utama Padang adalah kebutuhan dana. Kebutuhan dana yang meningkat pada masyarakat di Sumatera Barat membuat masyarakat lebih memilih menyimpan dananya dibank dari pada melakukan kegiatan bisnis. Apabila tingkat suku bunga konvensional yang tinggi maka masyarakat akan menyimpan dananya dalam bentuk simpanan deposito mudharabah pada Bank Nagari dibagian syariah untuk memperoleh keuntungan yang tinggi. Sesuai dengan data BI Rate pada tahun 2015 tingkat suku bunganya tinggi maka masyarakat Sumatera Barat menyimpan dananya di PT.Bank Nagari Utama Padang dalam bentuk deposito, sehingga simpanan depositonya mengalami kenaikan yang signifikan. Dengan tingkat suku bunga yang tinggi nasabah mengaharapkan keuntungan yang tinggi pada simpanan deposito. Hal ini sesuai dengan teori Kasmir (2013) semakin tinggi tingkat suku bunga maka semakin tinggi jumlah simpanan deposito.

\section{SIMPULAN}

Berdasarkan hasil penelitian mengenai pengaruh tingkat bagi hasil dan tingkat suku bunga terhadap simpanan deposito(studi pada PT. Bank Nagari Utama Padang periode Juli 2015- Desember 2017), dapat ditarik kesimpulan sebagai berikut:

1. Tingkat Bagi Hasil berpengaruh positif dan signifikan terhadap simpanan depositopada PT. Bank Nagari Utama Padang periode Juli 2015- Desember 2017. hal ini dinyatakan

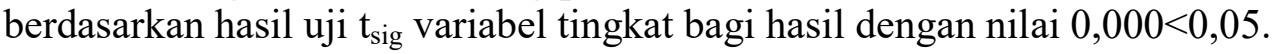

2. Tingkat Suku Bunga berpengaruh positif dan signifikan terhadap simpanan depositopada PT.Bank Nagari Utama Padang periode Juli 2015- Desember 2017. Hal ini dinyatakan berdasarkan uji $\mathrm{t}_{\text {sig }} 0,012<0,05$.

\section{UCAPAN TERIMA KASIH}

Terima kasih peneliti sampaikan kepada:

1. Bapak Febryandhie Ananda, SE, M.Si selaku ketua STIE"KBP" Padang yang telah memberikan fasilitas dan kemudahan kepada penulis sehingga studinya dapat berjalan dengan lancer.

2. Ibu Lidya Martha, SE, MM selaku wakil ketua STIE"KBP" Padang.

3. Ibu Afriyeni, SE, MM selaku direktur AKBP Padang.

4. Ibu Dewi Zulfia, SE,MM selaku ketua Program Studi Akuntansi Sekolah Tinggi Ilmu Ekonomi "Keuangan Perbankan Pembangunan" Padang.

5. Bapak Muhammad Rivandi, SE, M.Si selaku Dosen Pembimbing penulis, yang telah membimbing penulis dengan penuh kesabaran dari awal proposal sampai saat sekarang ini 
6. Ibu Lisa Amelia Herman, SE, M.Si selaku Dosen Pembimbing Akademik.

7. PT.Bank Nagari Utama Padang yang telah berkenan membantu dengan memberikan data laporan keuangan dalam penelitian ini.

8. Semua pihak yang telah memberikan dukungan beserta bantuannya dalam menyelesaikan skripsi ini.

\section{DAFTAR PUSTAKA}

Alinda, R. P. N., \& Riduwan, A. (2016). Pengaruh Tingkat Suku Bunga Bank dan Nisbah Bagi Hasil. Jurnal Ilmu Dan Riset Akuntansi, 5, 1-15.

Budisantoso, T., \& Triandaru, S. (2006). Bank dan Lembaga Keuangan Lainnya (edisi 2). yogyakarta: Salemba Empat.

Djuniadi, Afiffudin, M., \& Lestari, W. (2016). Statistik Inferensial. Semarang: Program Pascasarjana.

Farizi, F. Al, \& Riduwan, A. (2016). Pengaruh Inflasi, Suku Bunga, Likuiditas, dan Bagi Hasil terhadap Deposito Mudharabah. Jurnal Ilmu Dan Riset Akuntansi, 5, 2-16.

Ghozali, I. (2016). Aplikasi Analisis Multivariete (Edisi 8). Semarang: Universitas Diponegoro.

Iskandar, D., \& Firdaus, I. (2004). Pengaruh tingkat suku bunga , inflasi , dan kurs rupiah terhadap deposito mudharabah dan deposito bank konvensional pada perbankan di indonesia. Ilmu Ekonomi Dan Sosial, jilid 2, 336-344.

Kasmir. (2007). Dasar-Dasar Perbankan. Jakarta: PT. Raja Grafindo Persada.

Kasmir. (2012). Bank dan Lembaga Keuangan Lainnya (Revisi 12). Jakarta: PT Raja Grafindo Persada.

Kasmir. (2013). bank dan lembaga keuangan (revisi 201). Jakarta: PT RajaGrafindo Persada.

Kasmir. (2013). Dasar-Dasar Perbankan (Revisi). Jakarta: PT Raja Grafindo Persada.

Latumaerissa, J. R. (2013). Bank dan lembaga keuangan lain. Jakarta: Salemba Empat.

Lusiani. (2017). Pengaruh Tingkat Suku Bunga BI dan Inflasi terhadap Penghimpun Deposito Mudharabah. Institut Agama Islam Negeri Surakarta.

Mangani, K. S. (2009). Bank dan Lembaga Keuangan. (Adi Maulana, Ed.). Jakarta: Erlangga.

Natalia, E., Ar, M. D., \& Rahayu, S. M. (2014). Pengaruh Tingkat Bagi Hasil Deposito Bank Syariah dan Suku Bunga Deposito Bank Umum Terhadap Jumlah Simpanan Deposito Mudharabah (Studi Pada PT. Bank Syariah Mandiri Periode 2009-2012). Jurnal Administrasi Bisnis (JAB), 9(7), 1-7.

Ramadhan, M. (2008). Bank Syariah, (21), 16-51. 
Reswari, Y. A., \& Abdurahim, A. (2010). Pengaruh Tingkat Suku Bunga , Jumlah Bagi Hasil , Dan LQ45 Terhadap Simpanan Mudharabah Pada Bank Syariah di Indonesia. Akuntansi Dan Investasi, 11(1), 30-41.

Rumiati. (2010). Tinjauan Atas Bagi Hasil Dari Penjualan Buku Secara Online Pada Bandung Book Centre Palasari. Universitas Komputer Indonesia.

Sadi, M. (2015). Konsep Hukum Perbankan Syariah. Malang: Setara Press.

Saleh, R. (2002). Konsep, Produk, Dan Implementasi Operasional Bank Syariah. Jakarta: Djambatan.

Sudarsono, H. (2003). Bank dan Lembaga Keuangan Syariah. yogyakarta: Ekonisia.

Sugiyono. (2015). Statistika untuk Penelitian. Bandung: Alfabeta.

Syafi'i, M. (2001). Bank Syariah dari Teori Kepraktik. Jakarta: Gema Insani.

Taswan. (2008). Akuntansi Perbankan (III). Semarang: Upp Stim Ykpn.

Utomo, S. B. (2016). Perbankan Syariah. Jakarta: PT Raja Grafindo Persada.

Winarno, W. W. (2015). Analisis Ekonometrika dan Statistika dengan Eviews (4th ed.). yogyakarta: UPP STIM YKPN.

Yaya, R. (2014). Akuntansi Perbankan Syariah (2nd ed.). Jakarta: Salemba Empat. 